non for the origin of new species, but the origin of which character is as mysterious as the origin of a species itself!

Dr. Wallace affirmed that "no other agency" than " natural selection" has been shown as a probable cause of specific characters-and therefore of species. Possibly not. But if an asserted cause (X) has been shown to be incapable of producing a certain effect, it is no use to say : "It must be (X) because you cannot bring forward any definite (not X) as efficient to produce that effect." Surely it is enough to reply : "The cause you assert is insufficient, and we must therefore still remain in an attitude of doubt and expectancy."

1)r. Wallace, however, in his recent paper did admit that the distinctive characters of some exceptional species might not have been due to " utility" or "natural selection"; but such an admission seems to me a fatal one, for if an unknown cause may have given origin to some species, why may not such cause have been the really efficient agent in the production of all species?

But Dr. Wallace years ago made (and he has never since repudiated his act) a truly important exception to the action of " natural selection."

A survey of the organic world cannot certainly be a scientific one if the highest of animals (man) be left out of the account, nor can man be said to be scientifically treated if his highest characteristics be altogether neglected.

Dr. Wallace cannot be accused of such neglect, and therefore with a survey of the organic world thus scientifically defective. Taking account of man's highest intellectual powers, he has declared that "natural selection" must have been incompetent to produce them, and agreed with me in the conviction that they require some further and higher explanation.

A recent number of NATURE has contained a review of Prof. Weismann's paper read at Leyden. Therein, that ardent Darwinian appears to have made several notable concessions which bear upon the question treated by Dr. Wallace. One of these is that " mimicry" cannot be accounted for by accidental, individual variation; he appears to say the same concerning certain co-adjustments of instinct and structure, and he fully concedes the truth asserted by Mr. Herbert Spencer and by myself--the truth, namely, that panmixia cannot explain the annihilation of rudimentary organs.

$\mathrm{He}$, however, reaffirms his dictum that the idea of "teleological contrivances is inadmissible in science." But why? Who can deny to reason its right to investigate truth on all sides, and affirm that which appears to be evidently true with respect to any, including vital, processes? I adhere to the pronouncement of the world-renowned John Miuller : "Physiology is no true science if not in intimate union with philosophy." Once more I must urge that man and his highest intellectual powers cannot be excluded from a scheme of nature which is truly scientific. Man has intelligence, and acts more or less frequently with intelligent purpose- " teleological contrivance" -and he exists in a universe which, as a whole, can never have been submitted to the action of "natural selection." The universe, therefore, even if eternal, cannot have unreason for its cause, or any power devoid of intelligence and purpose.

I believe the indisposition to accept such truths as a part of science is largely due to our common tendency to permit the intellect to be fettered by the imagination, thus giving rise to anthropomorphic mental images, the absurdity of which is assumed also to belong to those intellectual conceptions with which they have infinitely less to do than have the signs of the zodiac with the coherence of the solar system.

Saltburn-by-the-Sea, June 29.

St. George Mivart.

\section{"The Reminiscences of a Yorkshire Naturalist."}

WHEN reading this very interesting record of my old friend and colleague (of which you gave such an excellent review in your issue of June 25), I found that, in his recollections of the days when we were both professors at the Owens College, Manchester, Dr. Williamson has been mistaken as to the details of Principal Scott's retirement. Mr. J. Holme Nicholson (late Registrar of this College) confirms my memory as to dates, and, at Mrs. Williamson's request, I ask you to kindly insert, in your forthcoming number, the following correction in her late husband's graphic account of the early struggles through which Owens College had to pass on the way to its present high position as an institution for sound instruction in natural science and original research.

NO. I 394, VOL. 54]
At page 140 of the "Reminiscences," there occurs the following passage: " Dr. Scott's resignation (May 28, 1857) robbed Manchester of a man of rare culture, and his death a few months later is said to have taken from the world more Dantesque learning than was left behind." There are two errors in this passage: in the first place, Dr. Scott did not sever his connection with Owens College in 1857 ; he resigned his principalship, but not his chairs of Logic, Moral and Mental Philosophy, and of Comparative Grammar and English Language and Literature, which he continued to hold until his death. Secondly, he died on January I2, 1866, and therefore not a fere months, but nearly nine years after his resignation of the principalship. Consequently, it is a mistake to infer that Manchester was robbed of his presence and the advantages of his learning in 1857.

This correction is the more important because Dr. Williamson's words, above quoted, and their context, seem to convey, I am sure quite unintentionally, the impression that Dr. Scott's death was hastened by his resignation of the principalship; whilst, on the contrary, his relief from one of his many arduous duties probably prolonged his interesting and valuable life.

E. FRANKLAND.

\section{The Tsetse Fly.}

In the excellent review of the Tsetse fly-disease, which appeared in NATURE of April I6, Mr. Walter F. H. Blandford accepts with some reserve the observation made by Dr. David Bruce, that the fly is viviparous "as the fly has not yet been bred from the puparium."

I pointed out to Dr. Bruce, while he was investigating the disease, that, with the systematic arrangement of Diptera now followed, I could hardly conceive the Glossina being viviparous; and I suggested the possibility of another fly being taken for the Tsetse. Dr. Bruce has not only been most emphatic in his reassertion, but I have myself since bred from three puparia, sent by him for that purpose, what is most certainly Glossina morsitans, Westwood.

South African Museum, Cape Town, June 15.

My hesitation in accepting unreservedly Dr. Bruce's account of the reproduction of Glossina was due to a suspicion, not that he had mistaken some other fly for it, but that the extruded larvæe might turn out to be those of a parasitic form, probably Tachinid. Mr. Péringuey's letter is most welcome as supplying the final proof of an extremely important fact, both economically and zoologically, in the insect's life-history.

There is much variety in the larval life of Muscida; and in Stomoxys, the genus most nearly allied to Glossina, the larva are normally scatophagous, but that of $S$. calcitrans has been occasionally found mining the leaves of burdock, coltsfoot and deadly nightshade.

Unfortunately, till proof is complete that Nagana is contracted under natural conditions from Tsetse-infection only, which is as yet far from being the case, we cannot console ourselves with the idea that the progressive extinction of African wild game must soon render the disease a thing of the past.

July 6 .

Walter F. H. BlandFord.

\section{The Salaries of Science Demonstrators.}

I SHOULD be glad if you would allow me the opportunity of endorsing Dr. Baker's protest contained in his letter in your issue of July 2, against the totally inadequate salaries offered by University Colleges to demonstrators and assistant lecturers in science.

Taking the subject of chemistry only: on looking over the official returns for the year $1893-4$, made by eight of the University Colleges participating in the Treasury grant of $t_{1} 5,000$, it will be seen that whereas the average salary paid to the professor is over $f 700$, that of the assistant lecturers and demonstrators is under $£ 150$, and in several cases below $£$ ioo per annum.

No one acquainted with what is required of them will maintain that the professors are overpaid, but all must admit that the remuneration of the lecturers and demonstrators is absurdly out of proportion.

Compare for a moment the work done by the two classes of teachers. The occupant of a chair of Chemistry in a University 